\title{
Solving Social and Demographic Problems as a Factor of Sustainable Development
}

\author{
Ph.D. Candidate Nodirbek Tula (Tashkent State University of Economics, Uzbekistan)
}

\begin{abstract}
In conditions of economic reforms, the demographic challenges and problems of the social protection of population stand at the forefront. In the field of demography it is quite essential to consider such factors as birth, mortality rates, marriages, divorces, age and sex structure and migration. In the social protection sphere the first major factors that we must pay careful attention are the number of pensioners, children and disabled people. In Uzbekistan, in recent years, fewer people have left the country. This is due to the gradual increase in the incomes and in the relatively homogeneous ethnic structure of the population. The age and sex structure of the population are changing, furthermore the population is gradually aging, which in turn will lead to a great demographic burden on the part of a certain age. In addition, the disparity of the gender in rural and urban areas, can lead adversely effect on the social life. It should be noted that in recent years there has been a tendency for an increase in the number of birth in absolute numbers and slowdown in its rate of percentage. This trend will effect to the economy of the country as a whole, as its regions as well. Therefore, it is necessary to carefully study the demographic processes, to develop a set of measures to balance social protection, growth rates and population migration.
\end{abstract}

\section{Introduction}

The growth of world population and production combined with unsustainable consumption patterns places increasingly severe stress on the life-supporting capacities of the earth. These interactive processes affect the use of land, water, air, energy and other resources. Rapidly growing cities, unless well-managed, face major environmental problems. The increase in both the number and size of cities calls for greater attention to issues of local government and municipal management. The human dimensions are key elements to consider, and they should be adequately taken into consideration in comprehensive policies for sustainable development. Such policies should address the linkages of demographic trends and factors, resource use, appropriate technology dissemination and development.

There is a need to develop strategies to mitigate both the adverse impacts on the environment of human activity and the adverse impact of environmental change on human populations. The world's population passed 6 billion in 2000 and is projected to reach 9 billion by 2050. Sixty percent of the current population already lives in coastal zones, while sixty-five percent of cities with populations above 2.5 million are located along the world's coasts, several of them already at or below the present sea level.

The gender structure changed because of decrease in rates of birth rate, but nevertheless today gender and age structure of the population, according to A.Sundberg's classification, has progressive type of reproduction of the population (Fig. 1).

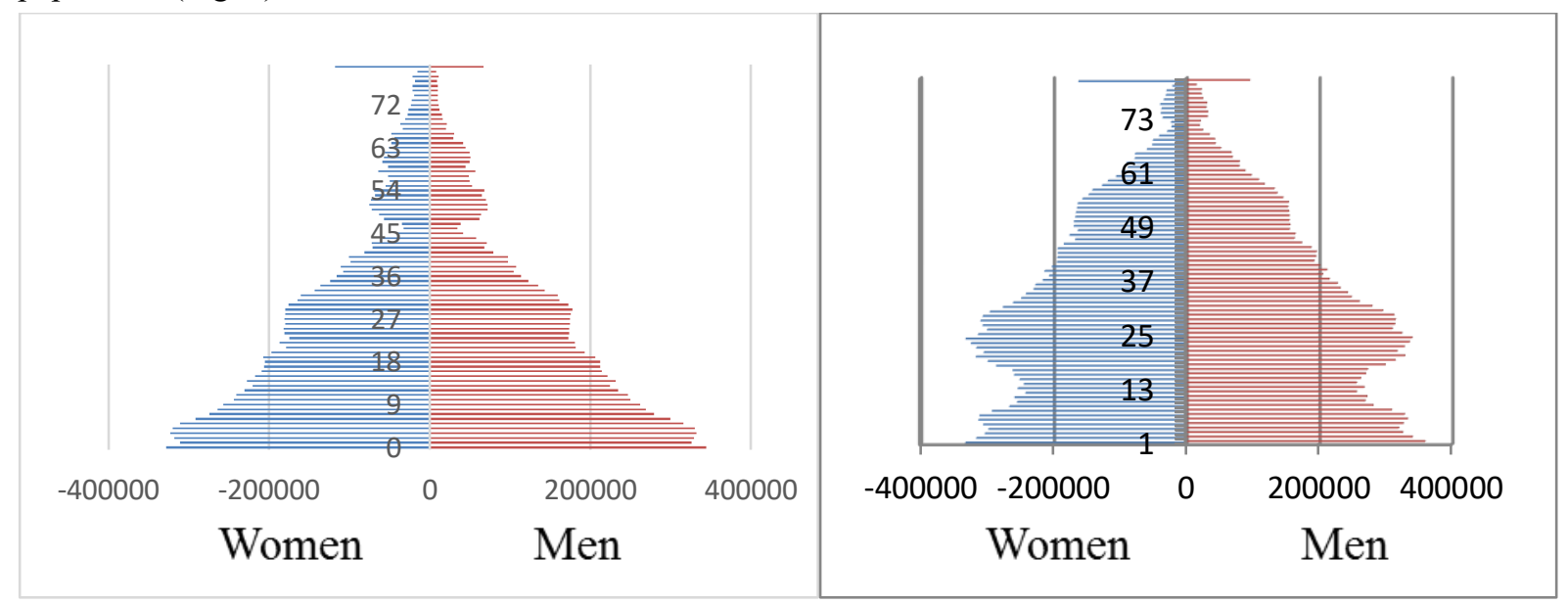

Figure 1. Gender and Age Structures of the Population of Uzbekistan for 1991 (at the left) and 2015 (on the right). Source: www.stat.uz 


\begin{tabular}{|l|c|c|c|c|c|c|}
\hline \multirow{2}{*}{ Age } & \multicolumn{9}{c|}{ Years } \\
\cline { 2 - 7 } & $\mathbf{2 0 1 1}$ & $\mathbf{2 0 1 2}$ & $\mathbf{2 0 1 3}$ & $\mathbf{2 0 1 4}$ & $\mathbf{2 0 1 5}$ & $\mathbf{2 0 1 6}$ \\
\hline All population (thousand people) & 29123,4 & 29555,4 & 29993,5 & 30432,8 & 31022,5 & 31575,3 \\
\hline All population \% & 100 & 100 & 100 & 100 & 100 & 100 \\
\hline Less than15 & 29,1 & 28,6 & 28,2 & 28,1 & 28,2 & 27,9 \\
\hline $15-24$ & 22,0 & 21,5 & 21,1 & 21,0 & 20,0 & 19,7 \\
\hline $25-49$ & 35,0 & 35,4 & 35,7 & 36,0 & 36,3 & 36,5 \\
\hline $50-64$ & 9,8 & 10,5 & 10,9 & 11,1 & 11,7 & 12 \\
\hline $65-69$ & 1,1 & 1,1 & 1,2 & 1,2 & 1,4 & 1,4 \\
\hline 70 and more & 3,0 & 2,9 & 2,9 & 2,7 & 2,6 & 2,5 \\
\hline
\end{tabular}

Table 1. Age Structure of the Population of Uzbekistan for 2011-2016. (in a percentage to the total number of the population). Source: www.stat.uz

The features of a gender and age pyramid of Uzbekistan influencing labor market formation is the high specific weight of the population aged up to 30 years. In 2015 the specific weight of youth aged up to 30 years was 59,7\% of all population of the country. In this regard the state needs close attention behind youth up to 30 years as it makes the majority of population.

The major indicators which are influenced on gender and age structure of the population, are the birth rate and mortality. In the beginning we will consider birth rate indicators.

\begin{tabular}{|l|c|c|c|c|}
\hline Years & Number of birth & Birth rate & In \% to previous year & In \% to 1991 \\
\hline 1991 & 723,420 & 3510 & 100 & 100.00 \\
\hline 1992 & 710,459 & 33.66 & 98.21 & 98.21 \\
\hline 1993 & 692,324 & 32.05 & 95.70 & 97.45 \\
\hline 1994 & 657,725 & 29.77 & 90.92 & 95.00 \\
\hline 1995 & 677,999 & 30.18 & 93.72 & 93.63 \\
\hline 1996 & 634,842 & 27.71 & 87.76 & 94.94 \\
\hline 1997 & 602,694 & 25.81 & 83.31 & 91.88 \\
\hline 1998 & 553,745 & 23.29 & 76.55 & 98.38 \\
\hline 1999 & 544,788 & 22.57 & 75.31 & 96.84 \\
\hline 2000 & 527,580 & 21.54 & 72.93 & 97.23 \\
\hline 2001 & 512,950 & 20.67 & 70.91 & 103.81 \\
\hline 2002 & 532,511 & 21.20 & 73.61 & 95.48 \\
\hline 2003 & 508,457 & 20.00 & 70.29 & 106.28 \\
\hline 2004 & 540,381 & 21.02 & 74.70 & 98.73 \\
\hline 2005 & 533,530 & 20.50 & 73.75 & 104.20 \\
\hline 2006 & 555,946 & 21.13 & 76.85 & 109.53 \\
\hline 2007 & 608,917 & 22.84 & 84.17 & 106.11 \\
\hline 2008 & 646,096 & 23.87 & 89.31 & 100.81 \\
\hline 2009 & 651,320 & 23.66 & 90.03 & 97.47 \\
\hline 2010 & 634,810 & 22.67 & 87.75 & 98.11 \\
\hline 2011 & 622,835 & 21.39 & 86.10 & 100.36 \\
\hline 2012 & 625,106 & 21.15 & 86.41 & 108.70 \\
\hline 2013 & 679,519 & 22.66 & 93.93 & 105.67 \\
\hline 2014 & 718,036 & 23.55 & 99.26 & 102.24 \\
\hline 2015 & 734,141 & 23.66 & 101.48 & \\
\hline
\end{tabular}

Table 2. Birth Rate Indicators in the Republic of Uzbekistan for 1991-2015. Source: www.stat.uz

Apparently from the table 2 coefficient of birth rate changed wavy and during the period from 1991 to 2001 had a steady tendency to decrease. During the period from 2001 to 2015 this indicator fluctuates from 20,50 to 23,66. In our opinion L.P. Maksakova gives the most exact description of this situation: "The birth rate in the republic becomes more and more adjustable in family. The state pursues policy of strengthening of the family relations, improvements of health of mother and younger generation with orientation to "reasonable birth rate" that yields real results" (Maksakova 2012).

One more important indicator of birth rate, the total coefficient of birth rate (TCBR) is. The ICR - is the most exact indicator of level of birth rate, this coefficient characterizes average of births at one woman in hypothetical generation for all her life at preservation of the existing birth rate levels at each age irrespective of mortality and 
from changes of age structure. Changes in fertility are important for definition of process of dynamics of development and influence on structure of age of the population. This coefficient pays off as the sum of specific coefficients of birth rate in a certain year (Ewa zofia Frątczak Demographic processes: past, present and future selected issues PAPERS on GLOBAL CHANGE, 20, 63-84, 2013).

\begin{tabular}{|l|l|l|l|l|l|}
\hline Period & $1990-1995$ & $1995-2000$ & $2000-2005$ & $2005-2010$ & $2010-2015$ \\
\hline Fertility rate & 3.95 & 3.10 & 2.51 & 2.49 & 2.38 \\
\hline
\end{tabular}

Table 3. Total Coefficient of Birth Rate of Uzbekistan for 1990-2015. Source: www.stat.uz

Except birth rate one more important indicator of the natural movement of the population, mortality is.

\begin{tabular}{|c|c|c|c|c|}
\hline Years & Number of death & Death rate & In \% to previous year & In \% to 1991 \\
\hline 1991 & 130294 & 6.32 & 100 & 100.00 \\
\hline 1992 & 140092 & 6.64 & 107.5199 & 107.5199 \\
\hline 1993 & 145294 & 6.73 & 103.7133 & 111.5124 \\
\hline 1994 & 148423 & 6.72 & 102.1536 & 113.9139 \\
\hline 1995 & 145439 & 6.48 & 97.98953 & 111.6237 \\
\hline 1996 & 144829 & 6.32 & 99.58058 & 111.1555 \\
\hline 1997 & 137331 & 5.88 & 94.82286 & 105.4009 \\
\hline 1998 & 140526 & 5.91 & 102.3265 & 107.853 \\
\hline 1999 & 130529 & 5.41 & 92.88601 & 100.1804 \\
\hline 2000 & 135598 & 5.54 & 103.8834 & 104.0708 \\
\hline 2001 & 132542 & 5.34 & 97.74628 & 101.7253 \\
\hline 2002 & 137028 & 5.46 & 103.3846 & 105.1683 \\
\hline 2003 & 135933 & 5.35 & 99.20089 & 104.3279 \\
\hline 2004 & 130357 & 5.07 & 95.89798 & 107.8983 \\
\hline 2005 & 140585 & 5.40 & 107.8461 & 107.1592 \\
\hline 2006 & 139622 & 5.31 & 99.31501 & 105.4768 \\
\hline 2007 & 137430 & 5.15 & 98.43005 & 106.5222 \\
\hline 2008 & 138792 & 5.13 & 100.991 & 102.545 \\
\hline 2009 & 133610 & 4.85 & 96.26636 & 106.2298 \\
\hline 2010 & 138411 & 4.94 & 103.5933 & 109.946 \\
\hline 2011 & 143253 & 4.92 & 103.4983 & 112.0451 \\
\hline 2012 & 145988 & 4.94 & 101.9092 & 111.8025 \\
\hline 2013 & 145672 & 4.86 & 109.78354 & 116.9408 \\
\hline 2014 & 149761 & 4.91 & 101.5184 & \\
\hline 2015 & 152035 & 4.90 & & \\
\hline
\end{tabular}

Table 4. Mortality Indicators in the Republic of Uzbekistan for 1991-2015. Source: www.stat.uz

Apparently from the table 4 the mortality rate smoothly grows from 6,32 per milles of 1991 to 6,73 per milles in 1993, the decrease trend till 2009 after that is observed. During the period from 2009 to 2015 the mortality rate keeps within 4,85-4,94 per milles. Today according to the UN the average general mortality rate is around the world estimated at 8,6 deaths on one thousand population. Proceeding from it, it is possible to note that mortality is in Uzbekistan at rather low level.

The following quality indicator of demographic process is the marriage structure of the population. The marriage structure of the population is a distribution of the population on a marriage state usually in combination with gender and age. Therefore often speak "marriage and age structure". The only source of information on marriage and age structure of the population are population censuses. The marriage state in a census is considered in the form of five categories now: never being married, being married at the time of the census, widow people, divorced legally and dispersed actually. At the same time the following age groups are allocated: up to 20 years, 20-24 years, further five-year age groups to group of 55-59 years, then an open interval "60 years are also more senior" than Tab. 4. 


\begin{tabular}{|c|c|c|c|c|c|}
\hline \multirow[t]{2}{*}{ Age, years } & \multicolumn{2}{|c|}{ Number of marriages } & \multicolumn{2}{|c|}{ Age structure of population } & \multirow{2}{*}{$\begin{array}{l}\text { Marriages rate per } 1000 \\
\text { people }\end{array}$} \\
\hline & units & $\%$ & thousands & $\%$ & \\
\hline All & 287582 & 100,0 & 31575 & 100 & 9,6 \\
\hline \multicolumn{6}{|l|}{ Including: } \\
\hline До 20 & 66440 & 23,1 & 15977 & 50,6 & 4,1 \\
\hline $20-24$ & 156157 & 54,3 & 2968 & 9,4 & 52,6 \\
\hline $25-29$ & 37484 & 13,0 & 2873 & 9,1 & 13,0 \\
\hline $30-34$ & 11363 & 3,9 & 2242 & 7,1 & 7,1 \\
\hline $35-39$ & 4600 & 1,6 & 1673 & 5,3 & 5,3 \\
\hline $40-44$ & 2000 & 6,9 & 947 & 3,0 & 1,0 \\
\hline $45-49$ & 927 & 3,2 & 947 & 3,0 & 1,0 \\
\hline $50-54$ & 667 & 2,3 & 979 & 3,1 & 0,7 \\
\hline $55-59$ & 285 & 1,0 & 884 & 2,8 & 0,3 \\
\hline 60 and older & 195 & 0,7 & 2084 & 6,6 & 0,1 \\
\hline
\end{tabular}

Table 5. Marriage and Age Structure of the Republic of Uzbekistan in 2015. Source: www.stat.uz

The marriage status of the population is the total of processes of the inference and cancellation of spoilage for rather long time frame. Distribution of the population on a status in spoilage develops as a result of the population coordinated correlations of age and sex structure, marriage rate and a divorces rate.

Apparently from about $55 \%$ of spoilage this table 14 falls to the share of the population of the second group at the age of 20-24 years. The highest indicator here coefficient of marriage rate is 52,6 people on 1000 these genders and ages. In process of reduction of a share of the gender and age population inverse process is brightly watched. Also the quantity got married and coefficients of marriage rate decreases as appropriate. So, if in age group of 2529 years specific weight them in marriage rate made $13 \%$ and also coefficient of marriage rate -13 per milles, then at the age of 60 and more of these indices decreased respectively to increase in level of marriage rate both among men, and among women. So, if in 2005 the general coefficient of marriage rate made 7,0 per milles that in 2015 increased up to 9,6 per milles.

The high level of marriage rate in case of a low divorces rate differs Uzbekistan from the majority of the countries of the world, but dynamics of increase in number of stains is watched in recent years. Only for 2005-2015 the total number of stains increased from 16,4 to 28,8 thousand people i.e. by 1,8 times. The Divorces rate (i.e. the frequency of cancellation of spoilage) also increased a little, having made respectively 0,6 and 0,9 stains on 1000 people of the population. As a result during the considered period I decreased stability of the matrimonial relations a little. If in 2005 it was the share of each 1000 spoilage the 89th divorce, then in 2015 already 97.

Deterioration in coefficient of stability of spoilage is partially caused by the fact that the number of stains increased quicker (1,8 times) than number of spoilage (1,6 times). Coefficient of advancing of a divorce made $12,5 \%$ for the considered period. And in recent years situation still worsened. The coefficient stated above increased only $2012-2015$ prior to $71,8 \%$ (Tab. 5).

\begin{tabular}{|c|c|c|c|c|c|c|c|c|c|}
\hline \multirow{2}{*}{ Years } & \multicolumn{3}{|c|}{ Marriages } & \multicolumn{3}{c|}{ Divorces } & \multicolumn{3}{c|}{ Divorces rate, per milles } \\
\cline { 2 - 10 } & All & $\begin{array}{c}\text { In the } \\
\text { city }\end{array}$ & $\begin{array}{c}\text { In the } \\
\text { country }\end{array}$ & All & $\begin{array}{c}\text { In the } \\
\text { city }\end{array}$ & $\begin{array}{c}\text { In the } \\
\text { country }\end{array}$ & All & $\begin{array}{c}\text { In the } \\
\text { city }\end{array}$ & $\begin{array}{c}\text { In the } \\
\text { country }\end{array}$ \\
\hline 2012 & 299,0 & 144,1 & 154,9 & 17,9 & 12,4 & 5,5 & 0,6 & 1,0 & 0,4 \\
\hline 2013 & 304,9 & 141,0 & 163,9 & 24,0 & 16,5 & 7,5 & 0,8 & 1,1 & 0,5 \\
\hline 2014 & 296,1 & 136,7 & 159,4 & 28,8 & 19,6 & 9,2 & 0,9 & 1,3 & 0,6 \\
\hline 2015 & 287,6 & 131,2 & 156,4 & 29,6 & 19,5 & 10,1 & 0,9 & 0,9 & 0,7 \\
\hline
\end{tabular}

Table 6. Number of the Registered Spoilage and Stains (thousands) Source: www.stat.uz

Apparently from the table much more to exceed the 5 th coefficients of a divorces rate at city dwellers a similar indicator of rural areas having made in 2015 respectively 0,9 and 0,7 per milles. Though in dynamics they decrease almost equally, making about 0,1 points in pro-mile expression annually.

Result of processes of a divorces rate is the number of the people considering themselves divorced or dispersed (if the divorce hasn't been issued legally). For 2012-2015 among men in general decrease in a share divorced and dispersed which is characteristic of all age, except for the youngest groups of the population up to 20 and 20-24 years was noted.

Migration plays an important role in development of demographic processes. In this regard, we will consider dynamics of mechanical motion of the population of Uzbekistan during 1991-2016 (Tab. 6). 


\begin{tabular}{|c|c|c|c|c|c|c|c|}
\hline \multirow{2}{*}{ Years } & \multicolumn{2}{|c|}{ Arrived } & \multicolumn{2}{c|}{ Leaved } & \multicolumn{2}{c|}{ Balance } & Migration \\
\cline { 2 - 8 } & $\begin{array}{c}\text { For 5 years } \\
\text { (thousands) }\end{array}$ & $\begin{array}{c}\text { Average } \\
\text { per year } \\
\text { (thousands) }\end{array}$ & $\begin{array}{c}\text { For 5 years } \\
\text { (thousands) }\end{array}$ & $\begin{array}{c}\text { Average per } \\
\text { year } \\
\text { (thousands) }\end{array}$ & $\begin{array}{c}\text { For 5 years } \\
\text { (thousands) }\end{array}$ & $\begin{array}{c}\text { Average per } \\
\text { year } \\
\text { (thousands) }\end{array}$ & $\begin{array}{c}\text { (per } \\
\text { miles) }\end{array}$ \\
\hline $1991-1995$ & 1412 & 282 & 1799 & 360 & -386 & $-78,0$ & $-3,6$ \\
\hline $1996-2000$ & 747 & 149 & 1024 & 205 & -207 & $-56,0$ & $-2,4$ \\
\hline $2006-2010$ & 723 & 145 & 991 & 198 & -268 & $-53,0$ & $-1,9$ \\
\hline $2010-2015$ & 746,0 & 149 & 937 & 187 & -191 & $-38,0$ & $-1,2$ \\
\hline
\end{tabular}

Table 7. Dynamics of Migration Processes in the Republic of Uzbekistan. Source: $w$ ww.stat.uz

There are arrived 282 thousand people and 360 thousand people left annually from 1991 till 1995 in the republic. Thus, the republic, has lost as a result of migration on average in a year 78 thousand people during 1991-2016 the size of a migration flow considerably fluctuated, and the intensity of migration decreased. The number left for the entire periods increased quicker, than arrived. Loss of the population as a result of migration process has decreased in recent years independence more than twice i.e. the balance of migration has decreased from 78 thousand people to 38 thousand persons.

In our opinion it is impossible to consider migration as unambiguously positive or negative phenomenon. From this party increase in quantity of left allow to remove stress from labor market, and the sdrugy party promote deficiency of labor as engine of economic growth. Disputes on impact of immigration on economic growth still proceeds and there is no uniform answer in the matter (Khalid Koser 2007). In opinion, George Bordzhas, the world's leading expert in the field of migration, "while theoretical work has achieved achievements in an explanation of possible communications between immigration and economic growth as soon as several empirical researches have been conducted, it became clear that there is no direct dependence between them".

The main indicator of sustainability is Human development index (HDI). The HDI is a summary measure for assessing progress in three basic dimensions of human development: a long and healthy life, access to knowledge and a decent standard of living. A long and healthy life is measured by life expectancy at birth. Knowledge level is measured by mean years of education among the adult population, which is the average number of years of education received in a life-time by people aged 25 years and older; and access to learning and knowledge by expected years of schooling for children of school-entry age, which is the total number of years of schooling a child of school-entry age can expect to receive if prevailing patterns of age-specific enrolment rates stay the same throughout the child's life. The standard of living is measured by Gross National Income (GNI) per capita expressed in constant 2011 international dollars converted using purchasing power parity (PPP) conversion rates.

Uzbekistan's HDI value for 2016 is 0.702 - which put the country in the high human development category positioning it at 105 out of 188 countries and territories. The rank is shared with Maldives. Between 2000 and 2015, Uzbekistan's HDI value increased from 0.594 to 0.701 , an increase of 18.0 percent. Table A reviews Uzbekistan's progress in each of the HDI indicators. Between 1990 and 2015, Uzbekistan's life expectancy at birth increased by 2.6 years, mean years of schooling increased by 2.9 years and expected years of schooling increased by 0.9 years. Uzbekistan's GNI per capita increased by about 91.5 percent between 1990 and 2015 .

\begin{tabular}{|c|c|c|c|c|c|}
\hline & $\begin{array}{c}\text { Life expectancy } \\
\text { at birth }\end{array}$ & $\begin{array}{c}\text { Expected years } \\
\text { of schooling }\end{array}$ & $\begin{array}{c}\text { Mean years of } \\
\text { schooling }\end{array}$ & $\begin{array}{c}\text { GNI per capita } \\
\text { (2011 PPP\$) }\end{array}$ & HDI value \\
\hline 2010 & 67.9 & 12.0 & 11.0 & 4,309 & 0.664 \\
\hline 2011 & 68.5 & 12.0 & 11.3 & 4,586 & 0.673 \\
\hline 2012 & 68.8 & 12.0 & 11.5 & 4,838 & 0.681 \\
\hline 2013 & 69.1 & 12.1 & 11.8 & 5,213 & 0.690 \\
\hline 2014 & 69.2 & 12.1 & 12.0 & 5,511 & 0.697 \\
\hline 2015 & 69.4 & 12.2 & 12.0 & 5,748 & 0.701 \\
\hline 2016 & 69.6 & 12.3 & $12 / 0$ & 5.981 & 0.702 \\
\hline
\end{tabular}

Table 8. Uzbekistan's HDI Trends Based on Consistent Time Series Data. Source: https://esa.un.org/unpd/wpp/Download/Probabilistic/Population/

\section{Conclusion}

On the basis of the analysis of demographic processes in Uzbekistan for 1991-2016 we can note the following:

- approximately equal number of men and women in the country (49,87\% - men and 50,13\% - women), we consider as a positive situation in which there is no tension connected with a disproportion of floors;

- $\quad$ high specific weight of the population aged up to 18 years (in 2016 the specific weight of children aged up to 18 years was $42 \%$ of all population of the country) and also the high specific weight of youth aged up to 30 years (in 2015 the specific weight of youth aged up to 30 years was $59,7 \%$ of all population of the country). This fact creates high financial load of the budget and society in general for development and maintenance of 
the relevant branches. In addition, the high coefficient of the dependents falling on one able-bodied family member $(0,74$ - in 2016), complicates process of growth in incomes of family, including per capita;

- at the same time the high specific weight of the persons who are annually entering working-age. It is connected with peak coefficients of birth rate in the 80th years and creates additional load of labor market now;

- average, but the birth rate level in recent years decreasing, can lead to aging of the population. Karimova D.M. and Tskhay L.A. considered that "The problem of aging of the population in Uzbekistan isn't relevant yet" ( Karimova D.M. and Tskhay L.A.2014), but according to the forecast which is calculated on the basis of data of UN DESA, process of aging will continue also in the 21st century, and the share of generation is more senior than 60 years can grow from $7,06 \%$ in 2015 to $19,62 \%$ by 2050 of the total number of the population. These data suggest that demographic aging in Uzbekistan will happen historically short time;

- increase in level of a divorces rate both among city and among country people. This tendency has negative effect on welfare development of the country. In society there are children from disabled families which in turn get to criminal structures more often.

- absolute measures of negative balance of migration decrease. In recent years the smaller number of people leave Uzbekistan. It is connected with gradual growth in incomes of the population and rather uniform ethnic structure of the population. So for example in the 90th years of which the peak of migration is the share it is connected with resettlement on the historical Homeland of ethnic minorities (Russians, Tatars, Koreans, etc.) from Uzbekistan.

\section{References}

- Ewa zofia Frątczak Demographic processes: past, present and future - selected issues PAPERS on GLOBAL CHANGE, 20, 63-84, 2013

- George Borjas Journal of Economic Perspectives, 9/2 (1995), 39

- https://esa.un.org/unpd/wpp/Download/Probabilistic/Population/

- International Migration: A Very Short Introduction Published in the United States by Oxford University Press Inc., New York Khalid Koser 2007

- Karimova D.M. and Tskhay L.A. Demographic aspects of social and economic development of Uzbekistan 2014 http://www.demoscope.ru/weekly/2014/0583/analit04.php

- Khalid Koser International Migration: A Very Short Introduction Published in the United States by Oxford University Press Inc., New York 2007

- L.P. Maksakova "The Demographic situation in Uzbekistan from the point of view of social safety" / Central Asia and the Caucasus t. 15 release 32012.

- Population and its problems Edited by H.B.Parry /Claredon press Oxford 1974 p55

- Roland Pressat Statistical Demography University press Cambridge 1978 p.80

- United Nations. The Determinants and Consequences of Population Trends. Department of Social Affairs, Population Division, Population Studies № 17. - New York: United Nations, 1953, pp. 181,221. 